\title{
Philopatry in a changing world: response of pink-footed geese Anser brachyrhynchus to the loss of a key autumn staging area due to restoration of Filsø Lake, Denmark
}

\author{
Kevin Kuhlmann Clausen ${ }^{1} \cdot$ Jesper Madsen $^{1}$
}

Received: 25 February 2015/Revised: 18 May 2015/Accepted: 14 July 2015/Published online: 4 August 2015

(C) The Author(s) 2015. This article is published with open access at Springerlink.com

\begin{abstract}
Site fidelity is a strong and widespread feature of many waterfowl species, but little is known about the response of philopatric birds to changing environmental conditions at their preferred staging sites. In this study we analyse the response of pink-footed geese Anser brachyrhynchus to the sudden loss of a major autumn staging area along their migration corridor, Filsø in Denmark, which followed the re-establishment of a former lake on open arable land serving as foraging site to tens of thousands of geese. Comparisons of goose usage before and after the restoration event revealed that (1) approximately $80 \%$ of pink-footed geese abandoned this staging area and (2) formerly site-faithful geese moved to other staging areas along the Danish west coast rather than moving further south to the Netherlands. Despite these significant changes in site use, the subsequent spring body condition of birds formerly philopatric to the Fils $\varnothing$ area was unaffected, suggesting that geese quickly moved to other areas and responded well to the sudden decline in available food at their formerly preferred staging site. These findings indicate that, at least for pink-footed geese, the cognitive plasticity necessary to alter site use allows a swift response to rapidly changing environmental conditions. This may partly be due to the agricultural habitat use of this species, leaving them plenty of alternatives in the modern Danish landscape.
\end{abstract}

Communicated by F. Bairlein.

Kevin Kuhlmann Clausen

kc@bios.au.dk

1 Department of Bioscience, Aarhus University, Kalø, Grenåvej 14, 8410 Rønde, Denmark
Keywords Site fidelity - Site faithfulness - Habitat loss . Waterbirds $\cdot$ Restoration $\cdot$ Migration

\section{Zusammenfassung}

Philopatrie in einer sich wandelnden Welt: Wie reagieren Kurzschnabelgänse Anser brachyrhynchus auf den Verlust eines wichtigen Herbstsammelplatzes durch die Renaturierung des Filsøsees in Dänemark?

Ortstreue ist bei vielen Wasservogelarten stark ausgeprägt und weit verbreitet; über die Reaktion ortstreuer Vögel auf sich wandelnde Umweltbedingungen an ihren bevorzugten Sammelplätzen ist allerdings wenig bekannt. In dieser Studie untersuchen wir die Reaktion von Kurzschnabelgänsen Anser brachyrhynchus auf den plötzlichen Verlust eines wichtigen Herbstsammelplatzes entlang ihres Zugkorridors in Filsø in Dänemark, der aus der Wiedervernässung eines früheren Sees auf offenen Ackerflächen resultierte, welche zehntausenden Gänsen als Nahrungsfläche dienten. Vergleiche der Nutzung durch die Gänse vor und nach dem Renaturierungsereignis belegten, dass (1) etwa $80 \%$ der Kurzschnabelgänse den Sammelplatz aufgaben und dass (2) vormals ortstreue Gänse lieber zu anderen Sammelplätzen entlang der dänischen Westküste wechselten als weiter nach Süden in die Niederlande auszuweichen. Trotz dieser erheblichen Änderungen in der Flächennutzung blieb die Körperkondition der früher zum Filsøgebiet philopatrischen Vögel im darauf folgenden Frühjahr davon unverändert, was nahelegt, dass die Gänse schnell in andere Gebiete wechselten und gut mit der plötzlich geringeren Nahrungsverfügbarkeit an ihrem ehemals bevorzugtem Sammelplatz fertig wurden. Diese Ergebnisse deuten darauf hin, dass zumindest bei Kurzschnabelgänsen die kognitive Plastizität ausreicht, um 
schnell auf sich rapide ändernde Umweltbedingungen reagieren zu können. Dies könnte in erster Linie daran liegen, dass diese Art Agrarhabitate nutzt, was ihr in der heutigen dänischen Landschaft reichlich Alternativen bietet.

\section{Introduction}

Waterfowl in general (Robertson and Cooke 1999) and geese in particular (Fox et al. 2002; Kruckenberg and BorbachJaene 2004; Phillips et al. 2003) are known to demonstrate a high degree of site fidelity for their staging areas, and many birds return to the same sites year after year. This faithfulness is undoubtedly coupled with quality features of specific staging sites remembered by individual birds, and may relate to abundant food, lack of predators, low frequency of disturbance, or any combination of these (Anderson et al. 1992; Robertson and Cooke 1999). The ability to remember suitable staging areas enables migrants to quickly replenish energy stores depleted on the preceding migration, energetically prepare for challenges ahead and reduce the risk of predation. When conditions change, however, site fidelity has also been shown to act as an ecological trap (sensu Dwernych and Boag 1972), where birds continue to return to a formerly good-quality site after environmental changes have caused the benefits of this area to decline (Ekroos et al. 2012; Ganter and Cooke 1998). This also leads to the conclusion that under highly fluctuating environmental conditions, philopatry may be disadvantageous (Mcnicholl 1975). Although philopatry is well documented for several waterfowl species, thus far very few attempts have been made to assess the consequences of environmental changes at sites to which waterfowl are faithful.

Like the strength of site fidelity, the ability to respond to environmental changes at stopover sites may vary substantially between species, and likely depends on the existence of (and distance to) other good-quality staging sites. As a consequence, species with restricted habitat choice and few available areas may suffer to a greater extent than species with flexible food choice and a selection of many and/or abundant habitats (Clausen et al. 2012; Fox et al. 2011). The ability of migrating birds to alter site use and migration patterns in response to habitat loss at stopover sites is dependent on the behavioral flexibility of individual species, and may theoretically affect departure load, mortality and phenology of individual birds (Weber et al. 1999).

While impact assessments of environmental change usually follow from deterioration of natural landscapes, the re-establishment of nature areas on former agricultural land is often similarly intrusive to their existing ecosystems.
One such restoration event took place in Denmark in 2012, when a contiguous area of 915 ha of open lowland agricultural fields were flooded to re-establish the former "Filsø Lake" in West Jutland, Denmark. Contrary to most landscape changes, which occur gradually over longer time horizons, with many internal and external confounding factors potentially affecting the responses observed, this single event triggered a natural experiment with sudden and large-scale changes in habitat availability. Within a few months, the landscape changed from vast expanses of open arable low-lying land to a 1-3-m deep lake. While this re-established wetland benefited many waterbirds in an otherwise agriculture-dominated landscape (Larsen et al. 2013), the now-flooded agricultural area was one of the most important autumn feeding sites for migrating pinkfooted geese (Madsen et al. 1999). This study is the first assessment of the response of geese to these dramatic landscape alterations, in which we investigate the changes in goose numbers on the site as well as the potential interaction with other staging areas. We aim to (1) describe the changes in numbers of pink-footed geese using the Fils $\varnothing$ staging site and alternative neighboring staging areas before and after the restoration event, (2) use neck-collared individuals to identify birds faithful to the Fils $\varnothing$ area and compare their site use before and after restoration, (3) evaluate whether the subsequent spring body condition of individuals philopatric to the Fils $\varnothing$ area suffered from the loss of a main staging site, and (4) discuss the ecological impact of site fidelity among migrating birds in light of habitat choice and environmental changes.

\section{Methods}

\section{Study population}

The Svalbard breeding population of pink-footed geese migrates via Norway to autumn and wintering areas in Denmark, the Netherlands and Belgium (Madsen 1984; Madsen et al. 1999). The population currently totals 76,000-81,000 birds (2013-2014), and has been steadily increasing over the last decades (Madsen et al. 2014). During the non-breeding period, pink-footed geese forage most commonly on energy-rich agricultural plant matter such as waste grain on cereal stubble fields, newly sown winter cereals, pastures, and newly sown spring cereal grain fields (Fox et al. 2005). Like other goose species, they prefer open areas that allow sufficient look-out for potential dangers (Madsen 1985a; Rosin et al. 2012). Nighttime roosting takes place on large water bodies or isolated islets in coastal areas, and most inland foraging flights are within a few kilometres of the roost, although distances up to $30 \mathrm{~km}$ are occasionally covered. 


\section{Focus area}

Prior to the nineteenth century, Fils $\varnothing$ was a large, 2800-ha coastal shallow lake, and an important staging and wintering site for numerous species of waterbirds in western Europe (Jepsen 2012). During the 1800s and 1900s, several rounds of land reclamation gradually reduced the lake's surface area to a mere 70 ha (what is nowadays known as Fidde Lake, Fig. 1). From 1947 until 2012, the entire drained lowland area served as intensive agricultural land, primarily used for growing cereals and seed grass (Lorenzen and Madsen 1986), and the highly cultivated open landscapes on the former Fils $\varnothing$ Lake bed became one of the most important autumn staging sites for pink-footed geese (Madsen 1984; Madsen et al. 1999). In the early 1980 s, over $90 \%$ of the entire population was counted on night roost in Fidde Lake within this area on a single day (J. Madsen, unpubl. data), and even after considerable population growth in recent decades, this number was still above $50 \%$ in the 2000s. Habitat use at Filsø is confined to agricultural areas, and geese forage on waste grain on stubble fields and graze on newly sprouted winter cereals (Madsen 1985b; Lorenzen and Madsen 1986).

In 2010, 2320 ha of the Fils $\varnothing$ area was bought by the Aage V. Jensen Naturfond (a private Danish nature conservation and wildlife protection fund) with the objective of restoring Fils $\varnothing$ Lake to a size of 915 ha water surface and surrounding natural area. Agricultural practice continued until 2012, when drainage was stopped, pumping stations removed and dikes leveled to the ground. In two phases (2 July and 7 October 2012), water was released back into the lowland, efficiently flooding the former fields to a depth of 1-3 m (Fig. 1).

\section{Changes in goose numbers}

As a measure of the importance of the Fils $\emptyset$ staging site, we relied on the maximum autumn count of pink-footed geese over a 4-year period prior to restoration (2008-2011), during the restoration year (2012) and 2 years post re-
Fig. 1 The Fils $\varnothing$ staging site showing traditional feeding area (solid white line), newly flooded range from the re-establishment of Filsø Lake (cross-hatched) and the traditional night roost of Fidde Lake (hatched). The inset map shows the position of Fils $\varnothing$ in relation to other autumn staging areas in Denmark

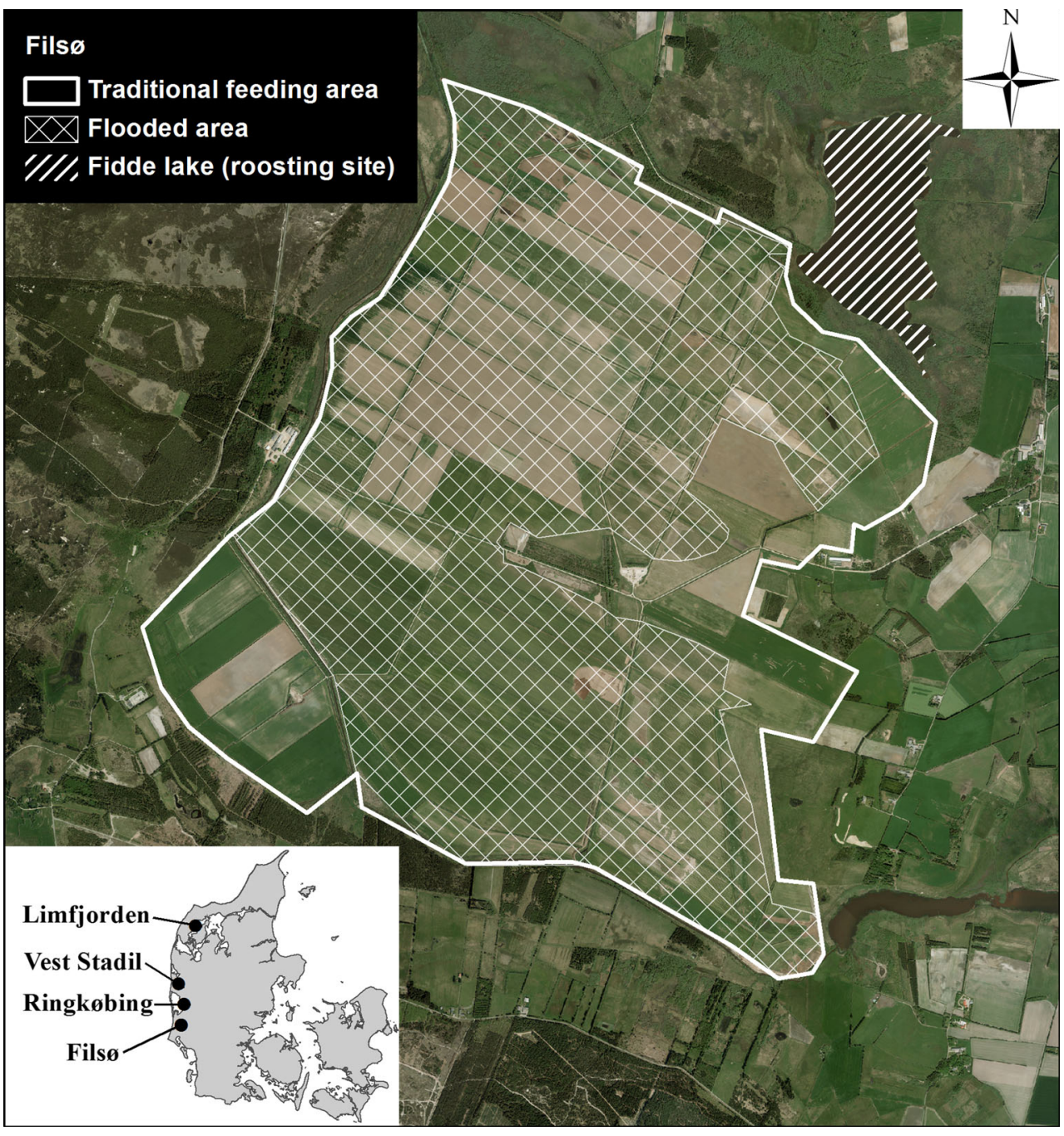


establishment of Filsø Lake (2013-2014). Maximum autumn counts from Filsø for all years were extracted from the DOFbasen (the online portal of the Danish Ornithological Society [Dansk Ornitologisk Forening]), and in order to clarify potential changes in the importance of neighboring autumn staging sites in response to the Fils $\varnothing$ restoration, similar extractions were made for three other major staging areas (please see section "Delineation of staging sites"). Maximum counts were derived from summaries of roost counts from known roost sites in each staging area within the same week. In the case of pinkfooted geese, the DOFbasen holds data from both systematic counts by trained observers, who specifically observe pink-footed geese 1-2 times per week at all major staging sites, and reporting by amateur volunteers. All maximum counts used in this study were reported by the trained observers.

\section{Response of site-faithful geese}

Pink-footed geese have been subject to a long-term ringing scheme that began in the late 1980s, and since 1990 geese have been fitted with individually recognizable neck collars enabling tracking of individual birds to study migration, dispersal and demographics (Madsen 2001; Madsen et al. 2002). Birds have been caught by either cannon-net captures in Denmark during the spring or roundups of moulting family groups on Svalbard during the summer, and the percentage of ringed birds in the population has generally been around $0.5-1.0 \%$ (Ganter and Madsen 2001). The presence of neck collars seems to have no longterm effect on the geese (Clausen and Madsen 2014). Identification of birds faithful to the Fils $\emptyset$ area was based on the criterion that individually marked geese had been observed and reported at the site in at least 3 of the 4 years prior to the restoration event. This criterion is rather strict, as geese may of course have visited the area without being reported. Although somewhat arbitrary, this approach (1) ensured that included birds indeed returned to this study area over a period of several years, and (2) provided a study period short enough to guarantee that significant numbers of birds survived the entire period. For birds fulfilling this criterion, we analysed annual site use (presence/absence: whether an individual was or was not observed in any given staging area) in September-October (time of peak migration in Denmark) for three periods corresponding to pre-restoration (2008-2011), during restoration (2012) and post-restoration (2013-2014). To guarantee a comprehensive and consistent re-sighting effort, systematic re-sighting campaigns have been carried out during autumn along the entire flyway of this population since 1990, ensuring several re-sightings of live birds during autumn migration (Madsen et al. 2002). In addition, the systematic sightings were supplemented by observations reported online by voluntary observers via the homepage www.geese.org. As a consequence of the topical issues and recent changes at Fils $\varnothing$, both the analyses of goose numbers and response of philopatric geese suffered from small post-restoration sample sizes. In both cases we rely on the $t$ test to analyse potential differences, as it has proven reliable with small sample sizes (de Winter 2013). In the current case, we believe that changes between the pre- and post-restoration periods are quite dramatic, and that the comparisons do not suffer from this limitation.

\section{Delineation of staging sites}

The autumn migration of pink-footed geese through Denmark is more or less north-south along the Danish west coast (Madsen et al. 1999), and the main staging sites along this corridor can be distinguished by latitudinal position. To elucidate potential changes in site use, we delineated all major staging sites (holding observations of $>5 \%$ of the population total during Sept.-Oct.) as a geographical space bounded by an upper and lower latitude. This ensured that all reported sightings of marked birds (with known latitude and longitude coordinates) could be traced to the correct staging site along the migration corridor. Based on this reasoning, we defined four major stopover sites in Denmark and a final wintering site in Friesland, the Netherlands (Table 1, inset of Fig. 1), corresponding to the most important autumn staging areas used by pink-footed geese (for details, see Madsen et al. 1999). Each of these sites is associated with separate night roosts in the form of a large water body or isolated islets.

\section{Effects on spring body condition}

Each spring in Denmark, a monitoring program of pinkfooted geese body condition is conducted, wherein the abdominal profile index (API) of individual geese is categorised on a scale of 1 to 7 . This measure is related to both body mass and total energy content (Madsen and Klaassen 2006), and is a broadly accepted proxy of goose body condition. All APIs are assessed by a small number of intercalibrated observers with extensive experience of scoring abdominal profiles in the field (detailed description given in Madsen and Klaassen 2006).

In the years post-restoration (2013-2014) we compared April (the main API assessment period) abdominal profile indexes from Denmark of geese philopatric to the Fils $\varnothing$ area with those of geese never observed at Fils $\varnothing$ during the study period. This analysis should reveal whether any longterm effects on body condition persisted in geese that lost Fils $\varnothing$ as a major stopover site during autumn migration. If a 
Table 1 Delineation of staging sites used by pink-footed geese during autumn migration

\begin{tabular}{lllc}
\hline Staging site & Lower latitude & Upper latitude & Distance from Fils $(\mathrm{km})$ \\
\hline Limfjorden & 56.58 & 57.10 & 125 \\
Vest Stadil Fjord & 56.12 & 56.25 & 56 \\
Ringkøbing Fjord & 55.83 & 56.10 & 33 \\
Filsø & 55.66 & 55.75 & 0 \\
Southwest Friesland & 52.82 & 53.32 & 345 \\
\hline
\end{tabular}

bird was scored more than once in the same period, the average was used.

\section{Results}

\section{Changes in goose numbers}

Maximum numbers of pink-footed geese at Fils $\varnothing$ were comparable for each of the years 2008-2010, at around 20,000, reaching approximately 39,000 in 2011 (Fig. 2a). This 2011 peak followed an extremely good breeding season, leading to an all-time high in population numbers (Madsen et al. 2014), but may also be linked to the presence of many unharvested cereal fields around Fils $\varnothing$ that year to which pink-footed geese were attracted (reported by the local manager). The 2011 peak corresponds nicely with a drop in numbers at the nearby Ringk øbing stopover, indicating an influx of birds from this site (Fig. 2b). During the year of re-establishment in the Fils $\varnothing$ area, the maximum number of observed geese was 13,000 , and although this halving in numbers corresponded well to an approximate halving in available area (first phase of flooding completed before arrival of the geese, second phase initiated shortly after arrival, see "Methods"), care should be taken not to overemphasize this result, because ongoing construction work may have also been an important factor. As a consequence, 2012 was omitted from further analyses. Post-restoration, the number of pink-footed geese at Filsø had decreased by $80 \%$, to an average of c. 4000 birds, which was significantly lower than before re-establishment of the Fils $\varnothing$ Lake $(N=6$, $t=6.338, P=0.005$; Fig. 2a).

Maximum counts from the other Danish autumn staging sites suggest that geese abandoning Fils $\varnothing$ moved primarily to Ringkøbing Fjord and Limfjorden, both of which experienced increasing numbers of pink-footed geese after the restoration of Filsø Lake (Fig. 2b). DOFbasen covers only Danish sites, but annual counts of pink-footed geese in the Netherlands further down the flyway have decreased in recent years (Hornman et al. 2015), indicating that geese redistributed within Denmark rather than continuing south.
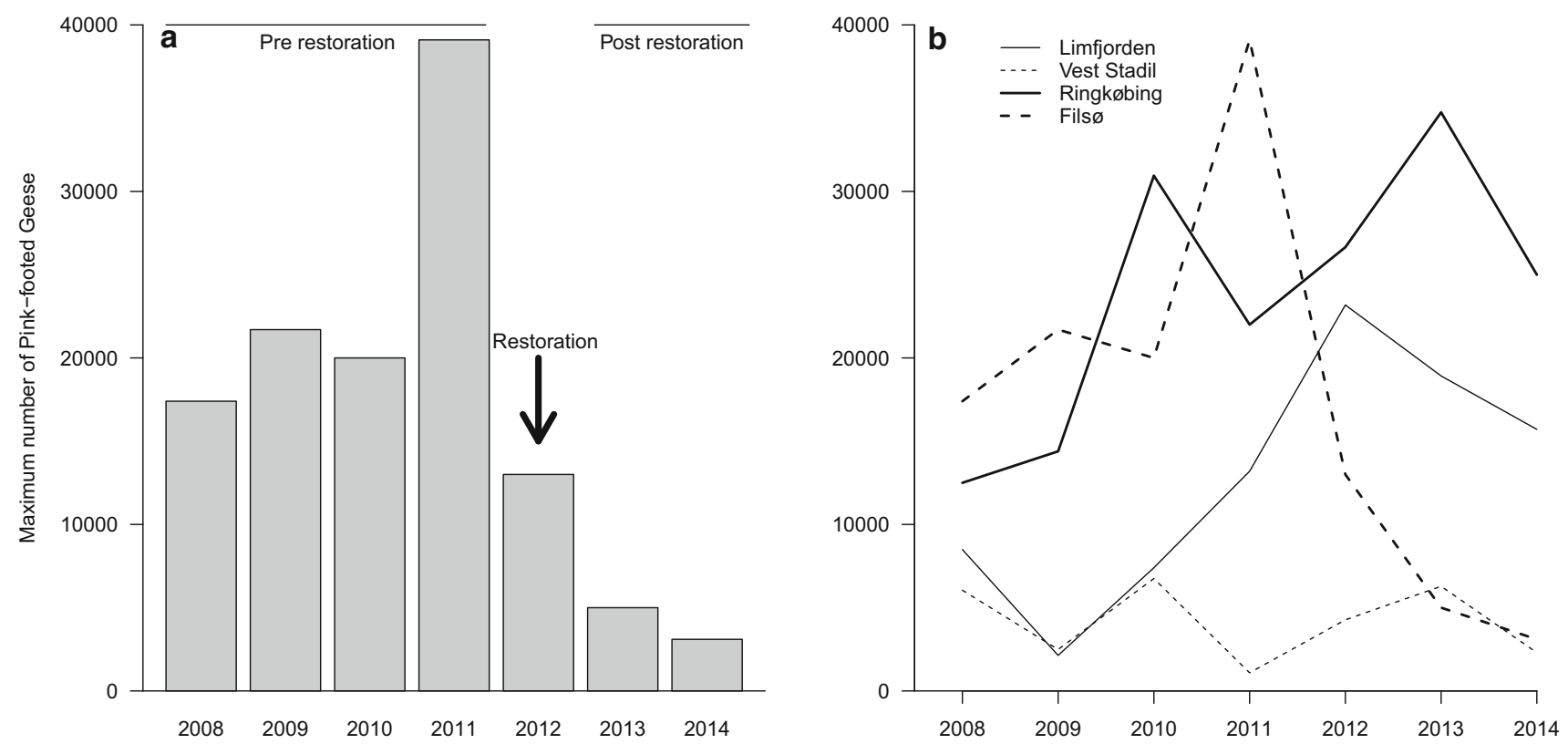

Fig. 2 Changes in maximum numbers of pink-footed geese during autumn at $\mathbf{a}$ Fils $\varnothing$ and $\mathbf{b}$ all major Danish staging sites during the period 2008-2014 


\section{Response of site-faithful geese}

Our criterion for site-faithful geese resulted in a total of 78 individuals considered philopatric to the Fils $\varnothing$ area. Most of these individuals were seen in all years during 2008-2010 (sample sizes given in Fig. 3), and $72 \%$ were observed in 2011. In 2012, 2013 and 2014, the proportion of these 78 birds observed anywhere in Denmark fell to 51, 41 and $28 \%$, respectively. Although this development translates to steadily declining sample sizes, it is also exactly what would be expected from the annual mortality rate of $17.1 \%$ (Madsen et al. 2002) and annual neck collar loss of $3.2 \%$ (Clausen et al. 2015) characteristic of the population. This is strong evidence that very few (if any) birds were entirely missed, due to the comprehensive and consistent re-sighting effort and systematic re-sighting campaigns (Madsen et al. 2002).

During the pre-restoration period (2008-2011), the annual return rate of site-faithful geese to Fils $\varnothing$ averaged $88.3 \%$, which after the restoration (2013-2014) declined to $9.3 \%(N=6, t=8.950, P=0.006$; Fig. 3$)$. In the year of re-establishment (2012), $45.0 \%$ of the geese were observed in the area. While Fils $\emptyset$ site use declined among geese formerly faithful to this area, their use of other staging areas increased (Fig. 3). In particular, Ringkøbing Fjord $(N=6, t=-9.391, P=0.001)$ and Limfjorden ( $N=6, t=-6.490, P=0.003$ ) seemed to experience an influx of birds formerly residing at Fils $\varnothing$ in autumn, while there was no change in numbers visiting Vest Stadil Fjord $(N=6, t=-0.618, P=0.578)$. These findings are very similar to patterns suggested by changes in maximum autumn counts across all staging sites (Fig. 2b). The proportion of geese observed in the final staging areas of Southwest Friesland, the Netherlands, did not increase from the pre- to post-restoration periods $(N=6$, $t=0.772, \quad P=0.483)$, indicating that rather than bypassing Fils $\varnothing$ and continuing down the migration corridor, pink-footed geese previously exploiting the Fils $\varnothing$ area searched for alternative sites in the vicinity of their formerly preferred staging site. This is further supported by the fact that at least $50 \%$ of philopatric geese observed at Fils $\varnothing$ post-restoration were observed further north later in the same 2-month period, thereby returning to previously overflown areas.

\section{Effects on spring body condition}

In the years following restoration, no differences in average April API were observed between geese philopatric to Fils $\varnothing$ $(N=18, \quad$ mean $\pm \mathrm{sE} 2.44 \pm 0.14)$ and geese never observed at this staging site during the study period $(N=123, \quad$ mean $\pm \mathrm{SE} \quad 2.33 \pm 0.06, \quad t=-0.700$, $P=0.490)$. Hence, individuals previously faithful to the
Fils $\varnothing$ area did not suffer any long-term effect on body condition during subsequent springs. This result was similar if only April 2013 (first spring after restoration) was used. To exclude the possibility that birds residing at Fils $\varnothing$ were energetically superior to individuals at other sites prior to the restoration event, we confirmed that there was no difference in average API in September-October prior to restoration between birds scored at Fils $\varnothing \quad(N=68$, mean \pm SE $2.20 \pm 0.07)$ and those in other staging areas $(N=56$, mean $\pm \mathrm{SE} 2.40 \pm 0.08, t=1.49, P=0.140)$.

\section{Discussion}

Findings in this study clearly demonstrate that the reestablishment of Fils $\emptyset$ Lake on former foraging sites of pink-footed geese has led to a substantial reduction in goose numbers in this staging area. Maximum numbers of geese observed at the site dropped to one-fifth of prerestoration numbers, and birds very faithful to the site moved to other staging areas. The spatial response of philopatric individuals was confined to other areas on the Danish west coast, indicating that these birds moved northwards to neighbouring sites instead of continuing down the migration route. Although nearly half of the birds moved to the nearest existing staging site (Ringkøbing Fjord), substantial numbers were also observed more than $100 \mathrm{~km}$ away at Limfjorden in the years following restoration. This might suggest that affected geese did not just disperse the shortest distance, but at least partly made an active decision in choice of staging site.

Spring body condition of Fils $\varnothing$ birds in the years after restoration was similar to that of individuals that did not use this staging site, indicating that negative energetic consequences were transient at worst. Although there was no support for a long-term effect on body condition, geese forced to search for new staging sites may still suffer from other demographic impacts such as increased hunting mortality. Hunting pressure may significantly influence site use among quarry species like pink-footed geese, and historically increased shooting at Fils $\varnothing$ has pushed geese further down the flyway by accelerating southward migration (Madsen and Jepsen 1992). Based on the number of re-sighted geese, our data indicate that survival in the year following restoration (autumn 2012 to autumn 2013) was approximately $32 / 40=0.8$, which is very close to the expected value of 0.797 estimated from annual survival in the 1990s and the retention of neck collars (Clausen et al. 2015; Madsen et al. 2002). Although an exhaustive analysis of survival is not possible based on currently available data, this indicates that mortality of former philopatric geese was not immediately affected by the loss of staging site. With regard to Filsø and hunting, waterfowl hunting 

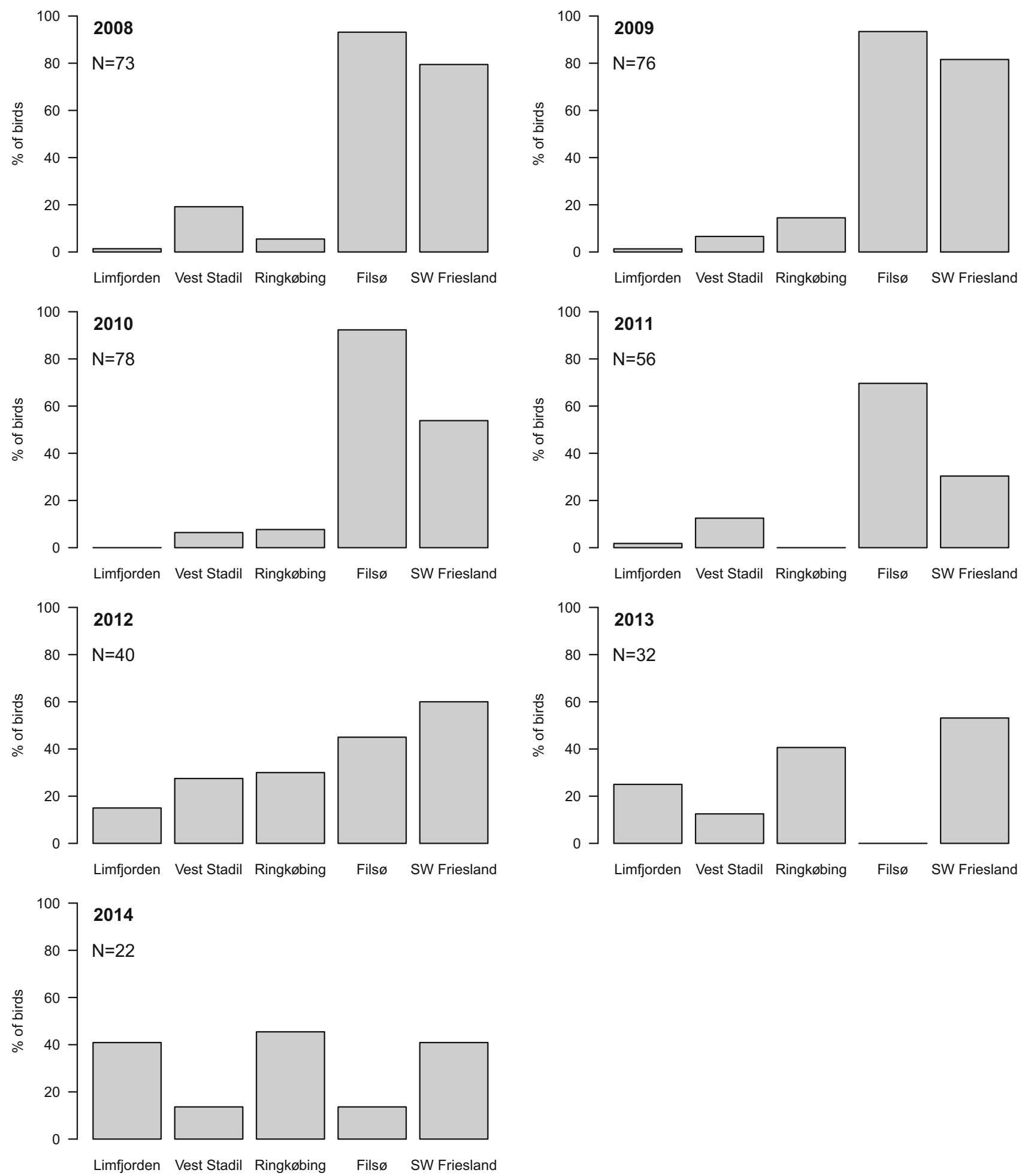

Fig. 3 Annual site use (percentage of birds visiting each staging site) of neck-collared pink-footed geese formerly philopatric to the Fils $\varnothing$ area in Denmark and the Netherlands during September-October over

the period 2008-2014. A value of $0 \%$ indicates that none of the geese made a stopover, while $100 \%$ specifies that all live birds did

has now been completely abandoned in the newly restored area, which should, if anything, encourage geese to use the site.

Traditionally, pink-footed geese have been believed to be very faithful in their choice of staging site, but results from this study would indicate that this species is fully 
capable to alter site use, highlighting an ability to respond immediately to changes in the environmental state of a main stopover site. The relative ease with which pinkfooted geese have been able to adapt to the loss of the Fils $\varnothing$ feeding site points to substantial cognitive plasticity that likely relates to its habitat use (Madsen 2001). The switch to an agricultural diet characteristic of both this population (Fox et al. 2005) and other species of geese (Rosin et al. 2012) opened the door to an almost inexhaustible food resource in the Danish landscape, and the availability of staging sites during the autumn migration may therefore depend more strongly on the relative proximity of secure roosting areas rather than specific food resources. As a consequence, philopatric waterfowl species exploiting cultivated areas might be much less susceptible to changes in staging areas than species targeting specific food sources much less available in a modern landscape (Clausen et al. 2012; Fox et al. 2011; Wang et al. 2012).

In the late 1990s, another traditionally important autumn staging site of pink-footed geese, Vest Stadil Fjord, underwent a restoration of wetland areas very similar to that at Filsø (Søndergaard et al. 2001). Although insufficient data of re-sighted geese precludes an analysis of philopatric responses in that area, the combined effects of losing the two most important autumn feeding sites in recent decades may have been an important driver of the ongoing spatially expanding autumn distribution among pink-footed geese (J. Madsen, unpubl. data). Not only have flocks of geese been observed further north and south on the Danish west coast, but increasingly higher numbers are also observed far inland, with daily flight distances of more than $20 \mathrm{~km}$ between roosts and foraging areas (J. Madsen, unpubl. data). This trend is further reinforced by the increasing number of pink-footed geese spending the entire winter in Denmark, thereby skipping the southernmost winter quarters in the Netherlands and Belgium (Hornman et al. 2015).

Further studies comparing the response of different philopatric species to the loss of preferred areas might enhance our understanding of the flexibility and adaptability of this waterfowl feature, and elucidate potential drivers of changes in site use and the associated costs and benefits. Considering the number of birds affected by the Fils $\varnothing$ restoration, negative outcomes could easily have triggered population-level consequences. However, adaptation in this species seems to be both rapid and relatively cost-free.

Acknowledgments We owe great thanks to everyone who has conducted neck collar readings and API assessments throughout the years, particularly Ole Amstrup, Mogens Bak and Jørgen Peter Kjeldsen, as well as all the committed people assisting the captures of pink-footed geese.
Open Access This article is distributed under the terms of the Creative Commons Attribution 4.0 International License (http://crea tivecommons.org/licenses/by/4.0/), which permits unrestricted use, distribution, and reproduction in any medium, provided you give appropriate credit to the original author(s) and the source, provide a link to the Creative Commons license, and indicate if changes were made.

\section{References}

Anderson MG, Rhymer JM, Rowher F (1992) Philopatry, dispersal, and the genetic structure of waterfowl populations. In: Batt BDJ, Afton AD, Anderson MG, Ankney CD, Johnson DH, Kadlec JA, Krapu GL (eds) Ecology and management of breeding waterfowl. University of Minnesota Press, Minneapolis, pp 365-395

Clausen KK, Madsen J (2014) Effects of neckbands on body condition of migratory geese. J Ornithol 155:951-958

Clausen KK, Clausen P, Faelled CC, Mouritsen KN (2012) Energetic consequences of a major change in habitat use: endangered Brent Geese Branta bernicla hrota losing their main food resource. Ibis 154:803-814

Clausen KK, Frederiksen M, Madsen J (2015) Measuring neck collar loss of pink-footed geese Anser brachyrhynchus. Bird Study 62:137-140

de Winter JCF (2013) Using the student's $t$ test with extremely small sample sizes. Pract Assess Res Eval 18:10

Dwernych LW, Boag DA (1972) Ducks nesting in association with gulls-ecological trap. Can J Zool 50:559-563

Ekroos J, Ost M, Karell P, Jaatinen K, Kilpi M (2012) Philopatric predisposition to predation-induced ecological traps: habitatdependent mortality of breeding eiders. Oecologia 170:979-986

Fox AD, Hilmarsson JO, Einarsson O, Walsh AJ, Boyd H, Kristiansen JN (2002) Staging site fidelity of Greenland White-fronted Geese Anser albifrons flavirostris in Iceland. Bird Study 49:42-49

Fox AD, Madsen J, Boyd H, Kuijken E, Norriss DW, Tombre IM, Stroud DA (2005) Effects of agricultural change on abundance, fitness components and distribution of two arctic-nesting goose populations. Glob Change Biol 11:881-893

Fox AD, Cao L, Zhang Y, Barter M, Zhao MJ, Meng FJ, Wang SL (2011) Declines in the tuber-feeding waterbird guild at Shengjin Lake National Nature Reserve, China-a barometer of submerged macrophyte collapse. Aquat Conserv 21:82-91

Ganter B, Cooke F (1998) Colonial nesters in a deteriorating habitat: site fidelity and colony dynamics of lesser snow geese. Auk 115:642-652

Ganter B, Madsen J (2001) An examination of methods to estimate population size in wintering geese. Bird Study 48:90-101

Hornman M, Hustings F, Koffijberg K, Klaassen O, Kleefstra R, van Winden E, Sovon Ganzen- en Zwanenwerkgroep, Soldaat L (2015) Watervogels in Nederland in 2012/2013. Sovon rapport 2015/01, RWS-rapport BM 14.27. Sovon Vogelonderzoek Nederland, Nijmegen

Jepsen PU (2012) Filsø. Museet for Varde By og Omegn, Varde, p 384

Kruckenberg H, Borbach-Jaene J (2004) Do greylag geese (Anser anser) use traditional roosts? Site fidelity of colour-marked Nordic greylag geese during spring migration. J Ornithol 145:117-122

Larsen JR, Hansen O, Rasmussen P, Bødker S, Nielsen SP (2013) Fuglene på Filsø, Årsrapport 2013, Filsøgruppen

Lorenzen B, Madsen J (1986) Feeding by geese on the Fils $\varnothing$ farmland, Denmark, and the effect of grazing on yield structure of spring barley. Holarctic Ecol 9:305-311 
Madsen J (1984) Numbers, distribution and habitat selection of pinkfooted geese Anser brachyrhynchus in Denmark 1980-83. Nor Polarinst Skr 181:19-23

Madsen J (1985a) Habitat selection of farmland feeding geese in west Jutland, Denmark: an example of a niche shift. Ornis Scand $16: 140-144$

Madsen J (1985b) Impact of disturbance on field utilization of pinkfooted geese in West Jutland, Denmark. Biol Conserv 33:53-63

Madsen J (2001) Spring migration strategies in pink-footed geese Anser brachyrhynchus and consequences for spring fattening and fecundity. Ardea 89:43-55

Madsen J, Jepsen PU (1992) Passing the buck: The need for a fly-way management plan for the Svalbard pink-footed goose. In: Roomen MV, Madsen J (eds) Waterfowl and agriculture: Review and future perspective of the crop damage conflict in Europe. The Ministry of Agriculture, Nature Management and Fisheries, The Netherlands and The International Waterfowl and Wetlands Research Bureau (IWRB), IWRB Special Publication 21, Slimbridge, UK

Madsen J, Klaassen M (2006) Assessing body condition and energy budget components by scoring abdominal profiles in freeranging pink-footed geese Anser brachyrhynchus. J Avian Biol 37:283-287

Madsen J, Cracknell G, Fox AD (eds.) (1999) Goose populations of the western Palearctic. A review of status and distribution. Wetlands International Publ. No. 48, Wetlands International, Wageningen, The Netherlands, National Environmental research institute, Rönde, Denmark

Madsen J, Frederiksen M, Ganter B (2002) Trends in annual and seasonal survival of pink-footed geese Anser brachyrhynchus. Ibis 144:218-226
Madsen J, Cottaar F, Amstrup O, Asferg T, Bak M, Bakken J, Christensen TK, Hansen J, Jensen GH, Kjeldsen JP, Kuijken E, Nicolaisen PI, Shimmings P, Tombre I, Verscheure C (2014) Svalbard pink-footed goose. Population Status Report 2013-14, Technical Report from DCE-Danish Centre for Environment and Energy No. 39. Aarhus University, DCE-Danish Centre for Environment and Energy, p 14

Mcnicholl MK (1975) Larid site tenacity and group adherence in relation to habitat. Auk 92:98-104

Phillips RA, Cope DR, Rees EC, O'Connell MJ (2003) Site fidelity and range size of wintering Barnacle Geese Branta leucopsis. Bird Study 50:161-169

Robertson G, Cooke F (1999) Winter philopatry in migratory waterfowl. Auk 116:20-34

Rosin ZM, Skorka P, Wylegala P, Krakowski B, Tobolka M, Myczko L, Sparks TH, Tryjanowski P (2012) Landscape structure, human disturbance and crop management affect foraging ground selection by migrating geese. J Ornithol 153:747-759

Søndergaard M, Madsen J, Hald AB, Aaser HF, Elmeros M, Kristensen P, Clausen P, Lauridsen TL (2001) Vest Stadil Fjord før og efter vandstandshævning, Technical report no. 355, Danish National Environmental Research Institute, p 56

Wang X, Fox AD, Cong PH, Barter M, Cao L (2012) Changes in the distribution and abundance of wintering Lesser White-fronted Geese Anser erythropus in eastern China. Bird Conserv Int 22:128-134

Weber TP, Houston AI, Ens BJ (1999) Consequences of habitat loss at migratory stopover sites: a theoretical investigation. J Avian Biol 30:416-426 